\title{
Tinau River Conservation and Integrated Water Resource Management
}

Abstract: This paper explores the lives of Tinau River and its inter-dependence with the basin communities and ecosystems in a holistic perspective. It seeks to share the influences of changing natural and anthropogenic processes on the river-catchment and how the resultant changes in river-basin influence the livelihoods and ecosystems. Taking an integrated approach of river-basin management, it aims to enhance basin-literacy by linking the ongoing processes in river-catchment, land use pattern and human activities.

Without environmentally-sound and sustainable integrated river basin management, it will not be possible to achieve self-sufficiency in food and energy. Tinau River management and conservation must aim to have a healthy river. Each type of water/resource use in the basin is managed in a fragmented manner by a separate department or agency. For healthy watershed development water resources of the river should be managed in a comprehensive manner. Policies, framework, methodology, legislation and institutions are to be developed and established for Integrated Water Resource Management (IWRM) of the river.

Key words: Basin-literacy, ecosystems, river-catchment, integrated management, Tinau River, sustainable development, Nepal, India

\section{Background}

This paper explores the lives of Tinau River and its inter-dependence with the basin communities and ecosystems in a holistic perspective. It seeks to share the influences of changing natural and anthropogenic processes on the river-catchment and how the resultant changes in river-basin influence the livelihoods and ecosystems. Taking an integrated approach of riverbasin management, it aims to enhance basin-literacy by linking the ongoing processes in river-catchment, land use pattern and human activities.

Achieving the right balance between ecosystem conservation and water resources development in the Tinau river basin represents a tremendous societal challenge. In Nepal not only is there weak and underdeveloped knowledge of environmental flows, but laws and regulations governing environmental flow allocations are almost non-existent. Furthermore, the public policy debate and the political process for setting socially and ecologically acceptable targets are too problematic and needs urgent improvement.

In light of these challenges, some opportunities for moving forward may be mentioned by the convergence of several threads in the public's slowly sprouting environmental awareness: the ecological costs of water resources exploitation are to be propagated; an understanding of the links between ecosystem health and societal well-being is yet to emerge; and the recent climate change phenomenon and the needs for adaptive planning are gradually recognized. But moving the dialog on freshwater sustainability forward needs leadership from the technical experts engaged in sustainable water development. Scientists, conservation NGOs, government agencies, water planners, and policy-makers all have a stake in collaboratively discussing how to strategically balance the needs for future water development with ecosystem sustainability at local levels. The involvement of water resources planners and managers is essential in this evolving dialog. Planners can take a leadership role by promoting a truly holistic vision of Integrated

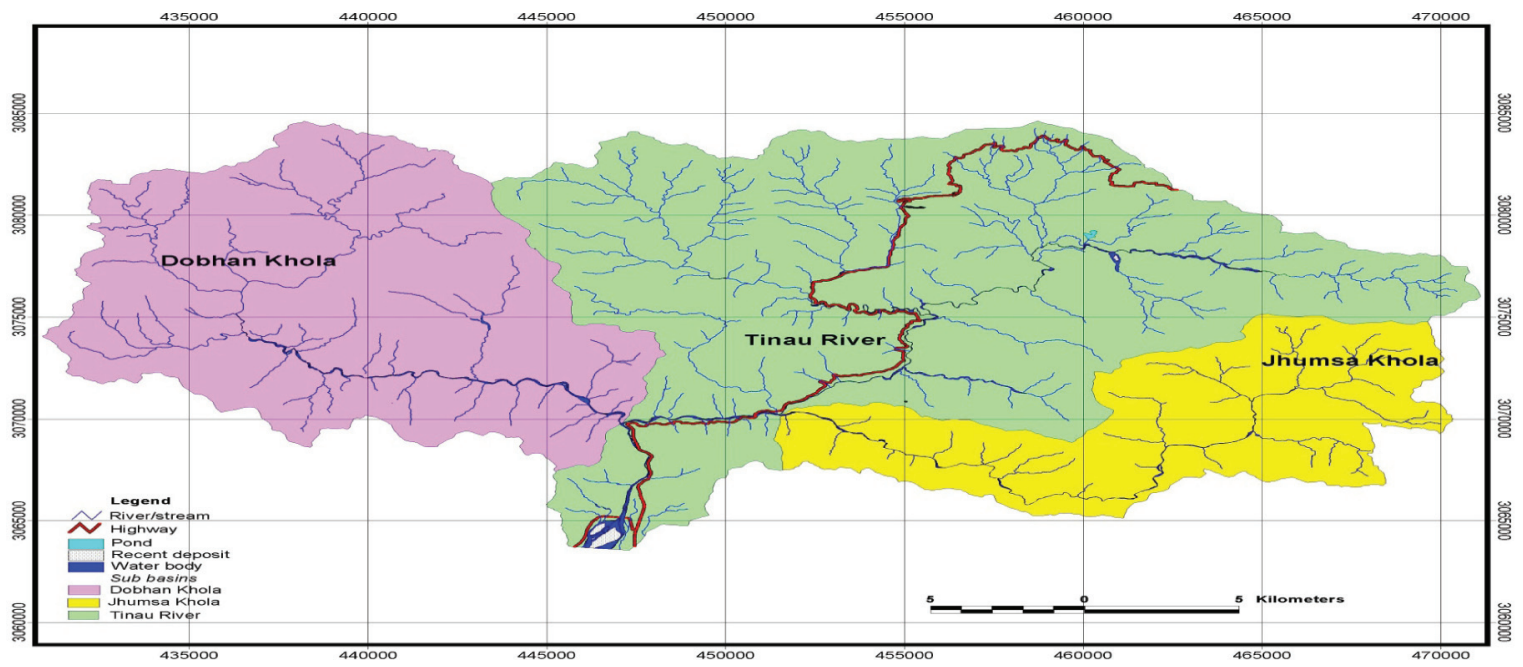

Figure 1. Watershed of the Tinau River.

(Source: Dahal 2009) 
Water Resources Management (IWRM), one that actively incorporates the need for adequate environmental flows. Sector professionals too often become narrowly focused in their specialties and that effective long-term management usually requires broader cross-disciplinary solutions.

\section{The Tinau River Characteristic \\ Catchment}

The Tinau River originates in the Mahabharat range of Palpa District in the Western Development Region of Nepal and debouches onto the Terai Plains before flowing into India, where it joins the West Rapti River near Gorakhpur, India. The total catchment area of the river up to the point of terminal at Gorakhpur is about $3,200 \mathrm{~km} 2$, of which about $850 \mathrm{~km} 2$ is in India. The area includes the Kothi and Beti rivers originating in the Churia hills of Nepal but meet the Tinau River in India. The Tinau River in Nepal has a total drainage area of about $1,200 \mathrm{~km}^{2}$. In the hills, the river drains an area of $560 \mathrm{~km}^{2}$, with the remainder in the Terai. The river flows through two districts: Palpa in the hills and Rupandehi in the Terai. The river debouches from the Churia hills to the Terai plain at Butwal. The catchment area of the river in the Terai plains of both Nepal

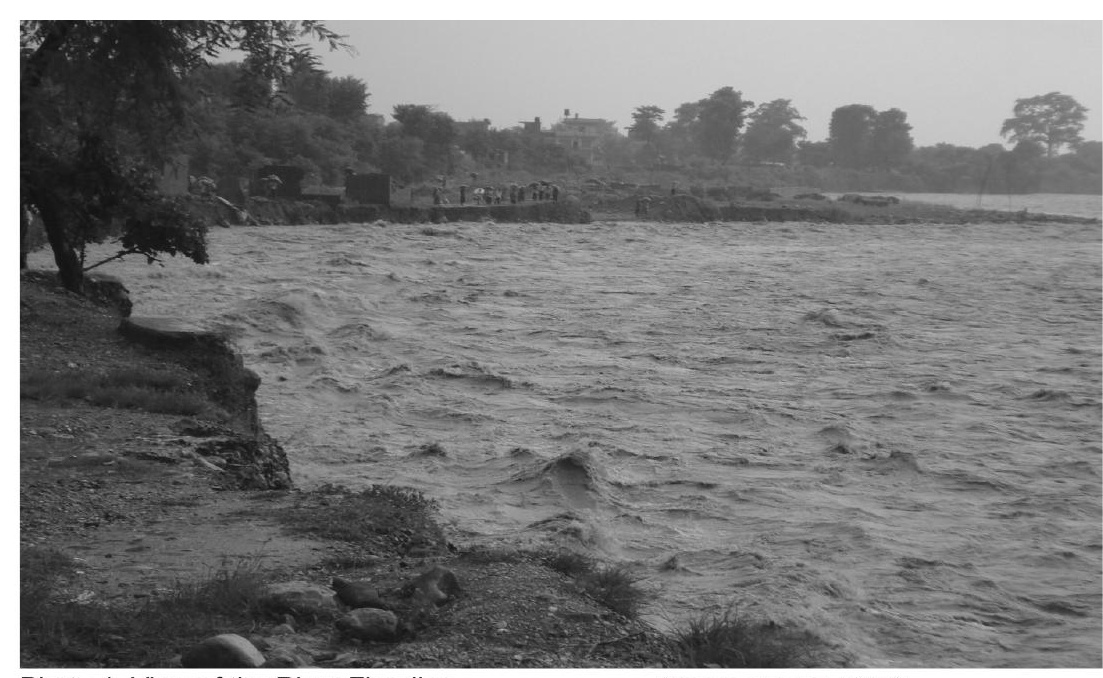

Photo 1. View of the River Flooding

(Source: Dahal 2009) nears to $1 \mathrm{~m}^{3} / \mathrm{s}$ and $3 \mathrm{~m}^{3} / \mathrm{s}$, respectively. Dry season flow is derived from the groundwater and base flow contribution. Floods are common during the monsoon. The average monsoon flow in August can be as high as $110 \mathrm{~m}^{3} / \mathrm{s}$ and the instantaneous flood peak is close to $2,500 \mathrm{~m}^{3} / \mathrm{s}$. Photo 1 shows the view of devastation by flooding.

Rupandehi District in Terai is one of the richest districts in groundwater potential. Unconsolidated sediments forming highly permeable aquifers, some of and India cannot be correctly defined mainly because it overlaps with areas of the Rohini River in the east and the Banganga in the west. The watershed of Tinau River is shown in Figure 1.

The Catchment area of the river as a whole is prone to landslides. There was a large landslide in the right bank of the river near Butwal that completely destroyed the newly constructed East West Highway Bridge in 1979. Also, further, north of the Butwal Technical Institute area a very large landslide destroyed dozen of homes.

\section{Climate}

The climate of the Tinau basin ranges from hot tropical in the southern Terai to warm temperate in the hills of Palpa District. In Terai summer temperatures reach $40^{\circ} \mathrm{C}$ while in the upper hills it remains cool. The main source of precipitation in the basin is the summer monsoon. The bulk of the annual rainfall (80\%) occurs between June and September and the remaining is received from the westerly during the winter months and pre-monsoon months. The average annual rainfall in the catchment is about 1,550 $\mathrm{mm}$. The Churia Range receives more than $2,300 \mathrm{~mm}$ of rainfall. Cloudbursts are common in the Churia hills and often cause massive floods and landslides. From time to time the river is temporarily dammed, which when it breaks causes flood havoc.

\section{Basin Hydrology}

Tinau River at Butwal is about $25 \mathrm{~m}^{3} / \mathrm{s}$, and at the border about $60 \mathrm{~m}^{3} / \mathrm{s}$, and the minimum flow in April

which are artesian, underline the plains of the district. The aquifers are recharged through inflow from the north and phreatic aquifers are recharged from percolation from traversing rivers and irrigated areas. Confined aquifers are currently under seasonably-varying artesian pressure. The average percolation rate is $350 \mathrm{~mm} /$ year, with which the natural replenishment of the aquifer system has been evaluated at nearly $470 \mathrm{MCM} /$ year (million cubic meters). Downward leakage in the basin from shallow aquifer into the deep aquifer is high (120 MCM/year). Details on ground and surface water interaction are available in the Bhairahawa-Lumbini Ground Water Project (BLGWP) report (DOI 1999). In several deep wells of BLGWP good artesian flows are available. In the upper hilly regions of Tinau, groundwater availability is considered low, which necessitates further study.

\section{Institutions and Development}

The Tinau basin includes the municipality area of Tansen in the hills, Butwal at the Churia foothills and Bhairahawa in the Terai. There are several villages along the North-South Highway that are evolving into small townships with dynamic commercial ad small-scale industrial activities. Good access to new infrastructure has strengthened traditional institutions as well.

The Tinau basin has a long history of settlement based on hydraulic civilization. Before and during the period of Gautam Buddha, the area was quite advanced. It has been well recorded that Lord Budha mediated the Rohini river water dispute between Sakya and Kolya clans. 
between the Kothi and Turia rivers. The Project has been executed in three successive stages since 1976 under the World Bank (IDA) credit and Nepal Government financing. The Stage I development was carried out from 1976-84 at a cost of US\$13.7 million (US\$9 million from IDA) and achieved 7,200 ha with 64 number of deep tubewells (DTWs) drilled. The Stage II development continued from 1984-1990 and costed US\$ 19.4 million (US\$ 16 million from IDA) with the development of 3,860 ha (47 DTWs), and Stage III from 1990-2000 and at a cost of US\$20.9 million (US\$ 15.6 from million IDA) and developed 9,249 ha (79 DTWs). Under all three stages of the project a total of 181 DTWs have been drilled of which 169 were operational and rest have been abandoned at the time of completion (2000). The actual irrigated area is less than $50 \%$ of the reported figure. Total withdrawals were estimated to be about $45 \mathrm{MCM} /$ year; but unfortunately, the recorded groundwater withdrawals during the years 1989-1997 ranged between 22.3 MCM in 1991 and 1.5 MCM in 1996 (Poudel, 2002). The use of the wells has been decreased gradually mainly due to frontal payment of electricity prices by the water users.

\section{Micro-Irrigation Technologies}

Both in hills and Terai areas, Micro Irrigation Technologies are gradually becoming popular. Highvalue crop farming and their marketing as well as multiuse systems are also introduced. In Madan Pokhara village in the hill district of Palpa, sprinklers and water harvesting technologies supply water for high value crops, especially vegetables marketed in the bazaar of Tansen and Butwal municipalities. In 1979, farmers began to use PVC pipes to tap streams, and spouts for sprinkler irrigation. Because of good income from vegetable farming and horticulture, many progressive farmers are adopting agriculture as their profession. Similarly, in the Terai low cost drip, treadle pumps and other alternative technologies are also in use.

\section{Drinking Water}

Tansen Municipality, Palpa District

Tansen Piped Water Supply System built in the early 1930 s from Banja Stream source is still surviving. In addition the town of Tansen has several stone water spouts. In 1972, the Holangdi Stream source was tapped and pumped to the reservoir at Basantapur. With assistance from the Japanese Government, the Bhulke system was developed in 1977. These systems are the source of drinking water for the hilly town of Tansen. Pumping water is a major consumer of electricity.

\section{Water Supply for Hill Villages}

Hill villages are using spring water either with the use of polyethylene pipes or with the stone spouts. Details of these efforts are not available.

\section{Butwal Municipality}

The town of Butwal had an old water supply system built in 1940s. Later, in 1965, the Indian Aid Mission augmented the system with water pumped from the Tinau River. Now Butwal has both formal and informal water supply facilities. The supply system uses three sources: groundwater, Tinau River and Chidia Khola. The operation and management of the system is under the Nepal Water Supply Corporation.

\section{Bhairahawa Municipality, Small Towns and Villages in Tinau Basin in Terai}

Drinking water system in Bhairahawa Municipality and townships like Manigram basically depend on groundwater from deep tube-wells with elevated water tanks and piped supply. Individual shallow tube-wells provide alternative spare sources in the middle class households. Most of the village water supply is from dug-wells or shallow tube-wells. Tinau and Dano Rivers are also widely used for drinking, as well as for local lift irrigation by the individual farmers.

\section{Hydropower}

The Tinau Hydroelectric Plant at the gorge just upstream of Butwal generates $1 \mathrm{MW}$ of power. A $65 \mathrm{~m}$ long weir across the river raises the water level by $8 \mathrm{~m}$, allowing flow to be diverted through a trash-rack to the desanding chamber where radial valves have been installed for intake control and sediment flushing. From there, water is taken to the powerhouse through a 1,26 m long tunnel of $2.1 \mathrm{~m}$ diameter. The underground powerhouse has three generating sets two of $0.25 \mathrm{MW}$ and one of 0.5 MW. Since the powerhouse floor is below the river level, seepage is a problem. During the floods the seepage water is collected in a tank using several pumps and drained out back to the river through a $752 \mathrm{~m}$ long tailrace tunnel. Stage-wise construction of the power plant was initiated by the Butwal Power Company (BPC) in 1966 and fully completed in 1978.

This Plant was instrumental in training Nepali Technicians/Engineers in many disciplines including tunneling, hydropower construction. At present, this plant is operating at only a fraction of the installed capacity. There are serious maintenance problems. It will be fruitful to lease out to a private Operator rather than under NEA (NEA Board has already approved for leasing out plants below $1 \mathrm{MW}$ capacity; but not of $1 \mathrm{MW}$ ).

\section{River Training and Flood Protection}

Every year the Nepal government allocates a substantial budget for river training and flood protection. Protection of Butwal municipality has become a continuing effort of the government and the public. Effective embankment construction has been the policy of the state. Although a master plan has been developed for river protection, the implementation is poor. So called Janatako Tatbandh (Peoples' Embankment) Program has spent substantial funds in poor quality embankment construction and its sustainability is doubtful. The target of involving local poor and vulnerable communities in construction for their livelihood has remained in slogans 


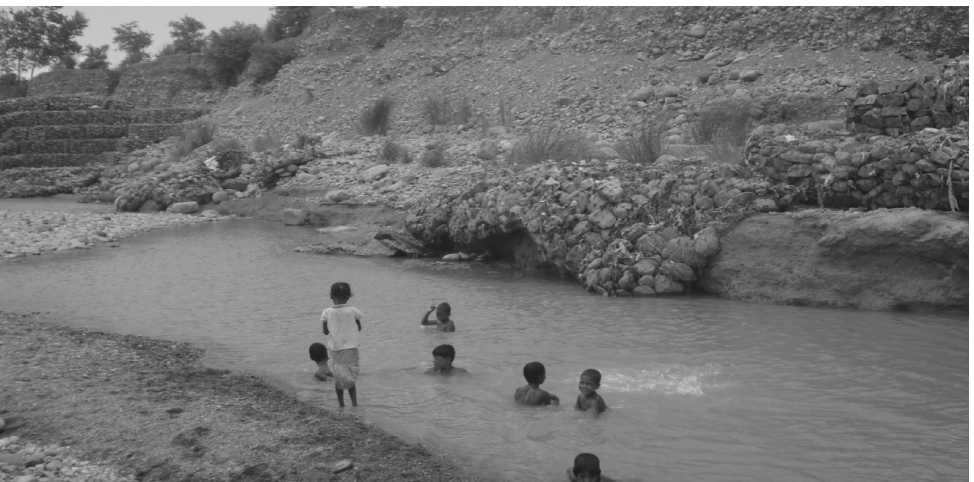

Photo 3. Bank Breaching Due to Deepening of River (Photo Source: Dahal 2009)

only. There was news in the media that recent monsoon flooding washed away part of the Peoples' Embankment.

\section{Extraction and Use of River Bed Material}

This river is extensively used for the extraction of bed materials (stones, cobles, gravels and sand) by many contractors, institutions and individuals. Much of these construction materials are exported to India. Unregulated extraction has created a major problem including substantial degradation of river morphology. Table 1 provides past 8 years extraction figure in the Terai area.

The yearly deposited riverbed material has been estimated to be 1.37 million cubic meter (MCM). The quantity of reserve riverbed material has been estimated at about 19.9 MCM (Dahal, 2009). But this volume includes the flood plain areas as well. At present the flood plain areas has been occupied by the landless people. The encroached area covers about $70 \%$ of the total flood plain area. This means the reserve material does not fulfil the high demand of existing crusher plants of the area for a long period. So there is no sustainability of crusher industries. Photo 4 provides the glimpses of river mining activities.

Due to over quarry of the river bed material, there has been substantial retrogression of the Tinau river bed. The Piers foundations of the East West Highway Bridge at the Butwal city are dangerously exposed. Recently, a number of cutoff walls constructed across the main course of the river. Its impact is yet to be seen.

\begin{tabular}{|c|c|}
\hline Year & Quantity, $\mathrm{m}^{3}$ \\
\hline $058 / 59 \quad(2001 / 02)$ & $7,40,000$ \\
\hline 059/60 (2002/03) & $1,150,000$ \\
\hline 060/61 (2003/04) & $2,050,000$ \\
\hline 061/62 (2004/05) & $2,600,000$ \\
\hline 062/63 (2005/06) & $2,650,000$ \\
\hline $063 / 64(2006 / 07)$ & $2,750,000$ \\
\hline $064 / 65(2007 / 08)$ & $2,550,000$ \\
\hline 065/66 (2008/09) & $2,150,000$ \\
\hline Total & $16,640,000$ \\
\hline
\end{tabular}

Table 1. Quantity of River Bed Extraction (Source: Dahal 2009)

\section{Industrial Uses}

Bhairahawa-Butwal and Bhairahawa-Lumbini belts are gradually developing into an industrial hub of the Western Development Region. So far industrial water consumption has been assessed to be about two percent.

\section{Other Uses}

Income from fisheries is not high, though several poor families depend on fishing. The river is also used for religious and cultural purposes. Cremations of dead bodies on the river bank are the usual ritual of the Hindu community. Recreational use is found to be limited.

\section{River Bank encroachment by Squatters (Sukumbasi)}

The economic opportunities created by the extensive extraction of river bed materials have invited river bank encroachment by the squatters along the river in Terai (Photo 4). Even in the left bank of Tinau in the main Municipality area, the River area (cremation areas) has been encroach, there happens tension for the cremation of the dead bodies.

The river water quality is degraded due to sewage from the habitation along the bank upper part of the Butwal municipality area. The right bank after the Jit Gadi Fort, all land in the south was once forest (till 1972) now there are dense habitation to several hundred meters down. This is an example of systematic grabbing the forest land in Nepal.

\section{Institutions Involved in Resource Use and Management}

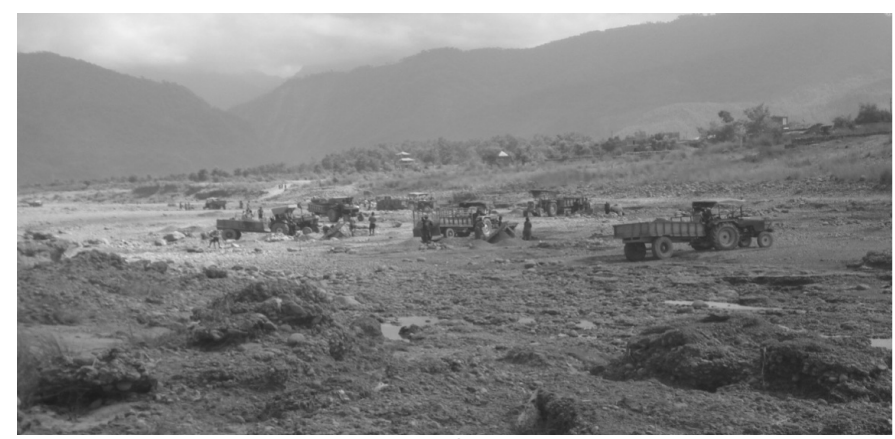

Photo 4. View of River Mining

(Source: Dahal 2009)

There are several ministries that look after various water related activities. The divisions of responsibilities of each ministry are as follows:

- Ministry of Irrigation: irrigation and water induced disaster prevention.

- Ministry of Agriculture: all agricultural activities.

- Ministry of Energy: hydropower.

- Ministry of Physical Planning and Works: water supply, sanitation and roads.

- Ministry of Environment: environmental issues.

- Ministry of Local Development: rural and local issues, as well as control and use of river bed materials.

- Ministry of Health: health promotion.

- Ministry of Education: schools and educational 


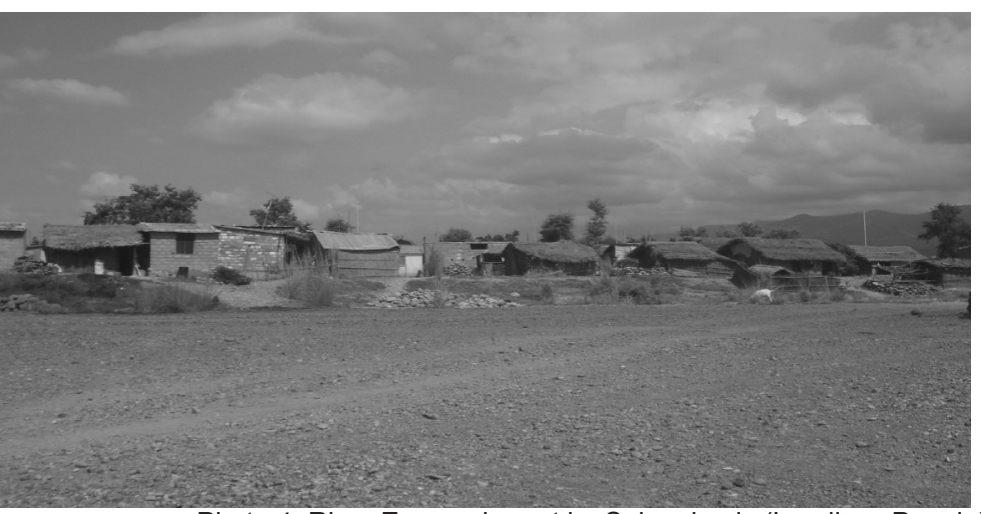

Photo 4. River Encroachment by Sukumbasis (Landless People) (Source: Dahal 2009)

matters.

- Ministry of Home Affairs: resource allocation, disaster prevention, security issues and general administration.

- Ministry of Forest: forest \& watershed management.

- Ministry of Industry: industrial and river bed material other than water management.

- And many others.

Because of long-standing rivalries, coordination and cooperation between the various ministries are problematic. In large-scale water development all these issues must be integrated within the project area as well as within the basin. An integrating institution at this juncture is non-existent. The Ministry of Water Resources was legally mandated and was to look after the issues of water in a comprehensive and holistic manner. In 2009, the government unwisely abolished this Ministry existing for more than two decades and in its place created two new ministries: Irrigation and Energy, just to create additional two ministerial posts. At this juncture there is no ministry legally mandated to look after water issues in a comprehensive manner. The Ministry of energy has been given an ad-hoc authority by the Cabinet for the time being. This type of baseless and unscientific political intervention in development efforts will create long lasting and irreversible damage to the future of the country.

While it is easy to point out that all the rivers are to be managed in an integrated way, effecting this integration in reality in the field is a very complex and daunting task. To date, it has become a rhetorical and theoretical propagation only, and hardly any success stories are available in Nepal.

\section{Environmental Management Watershed Management}

Aggregated impacts of unplanned and ad-hoc development activities continuing for decades or even for centuries over the entire watershed of the river has created insurmountable problems. Human and livestock populations are continuously rising in the basin. Land use patterns of the river watershed have undergone serious changes due to the combined effects of agricultural \& industrial development, deforestation and the encroachment by the slum dwellers within the flood plains. It is likely to be subjected to more adverse changes in coming years. The status of environmental degradation in the hill areas and also in Bhabar zones is already alarming. (Bhabhar is the region just south of the Siwalik Hills. It is the alluvial apron of sediments washed down from the hills and mountains, which has high water infiltration rate) Landslides, erosion and mass-wasting have become regular phenomena.

The recent development patterns are quite unsustainable. Forceful policy of exclusion/evacuation of humans and livestock from vulnerable areas only can satisfy the needs of sustainability. Proper watershed management has already become urgent, requiring simultaneous achievement of many tasks, including afforestation, strict control of land use practices, and more emphasis on small-scale structures such as check dams for better soil and water conservation. Use of bioengineering methods for protection of landslides and erosion should be made mandatory for the infrastructure development in the hill areas.

\section{Water Quality Management or Pollution Control}

The surface water quality of the river is rapidly degrading. Both point and non-point sources of water pollution are increasing along the river. Municipal, agro-industrial, domestic and industrial wastewater are important point sources of pollution. Non-point sources such as soil erosion, mass-wasting and sediment transportation have resulted in habitat alteration and adverse effects on aquatic life. Nutrients, heavy metals and toxic chemicals mainly from fertilizers, pesticides and other industrial products are also polluting the stream flow. Irrigation return flows and runoff from animal farms also contains substantial pollutants.

Water quality management legislation is lacking and it should be formulated and adopted as soon as possible. It should be consistent with national requirements of economic and social realities, and human resource capabilities.

\section{The River Use in India}

The Tinau (Dano) is called Kuda River in India until it joins West Rapti River near Gorakhpur about $30 \mathrm{~km}$ downstream of the international border. Before the confluence it is fed by number of smaller tributaries including the Tellar, Jamuar, Bilar and Ghangi rivers.

In India, the water use systems along the river are not as well defined as in Nepal. This river is used for drinking, as well as for local lift irrigation. There are no flow records of the river, but good low season flow is present, due to seepage. The major intervention by the government in water management along the river consists of disjointed ineffective embankments for flood control. In the Indian part of the Tinau basin use of ground water is extensive and widespread.

\section{Future Plans}

\section{Trans-basin Water Diversion}

It has been identified that water shortage of the Tinau 
basin can be augmented through diversion of surplus water of Kali Gandaki river with the help of a $25 \mathrm{~km}$ long diversion tunnel. Preliminary study shows that with the diversion of $50 \mathrm{~m} 3 / \mathrm{s}$ of discharge to Tinau River the scheme could generate $50 \mathrm{MW}$ of hydro-power and irrigate almost 100,000 ha of fertile land of the western Terai. This scheme needs detailed study before making a decision for implementation. The tentative cost of the scheme is about US\$400 million. An irrigation headwork and canal systems on both banks of Tinau River and a hydro-power plant have been included in this plan.

\section{River Training Master Plan}

The Department of Water Induced Disaster Prevention (DWIDP) has developed a Master Plan for the River Training of the Tinau River in the Terai. Gradual implementation of the plan has been initiated.

\section{River Material Use Master Plan}

The Tinau River has been extensively used for river bed material extraction. It has been estimated that each year Rs. 2.5 billion (US $\$ 34.7$ million) worth of boulders, cobles, gravels and sand are extracted and sold in nearby markets and exported to India. Unplanned activities have created serious environmental hazards. Hence, a scientific master plan development has become an urgent need.

\section{Public Involvement}

An effective and sustainable strategy for public involvement in water sector planning is to be developed and implemented. This strategy, in addition to others, should include opinion polls and surveys, socio-economic impact assessment, referenda, public hearings, advocacy planning, pressure groups, public meetings, workshops or seminars, task-force, etc.

\section{Constraints in IWRM of Tinau River}

There are many constraints inhibiting IWRM on the Tinau river, including:

- River basin approach in planning has not yet been formalized and legislation not developed.

- Lack of appropriate methodology.

- Lack of adequate knowledge and absence of appropriate research to develop new technologies and approaches, and absence of incentives to adopt them.

- Severe institutional constraints: sectoral approach to development of water projects.

- Coordination and cooperation between various agencies in practice is lacking.

- No agency for integrated management.

- Lack of appropriate and consistent policies for water development.

- Absence of effective monitoring, evaluation and feedbacks.

- Lack of proper policies on cost recovery and water pricing and absence of their implementation.

- Debts and financial deterioration, lacking funds, delays in allocating funds for operation and maintenance.
- Deterioration in data collection efforts, even hydrometeorological data are scanty and collection discontinued; no data on pollution and other issues.

- Lack of donor coordination resulting in different approaches and methodologies, and thus conflicting advice.

- Lack of sound planning and decision making framework.

- Lack of sound institutional, legal and financial framework. Existence of rampant corruption resulting in poor quality of work.

- Lack of effective users' participation in planning, implementation operation of the government developed schemes.

- Serious delays in completing water projects after major investments like headwork and other major hydraulic structures in place.

\section{Conclusion and Recommendations}

Without environmentally-sound and sustainable integrated river basin management, it will not be possible for the Tinau basin to achieve self-sufficiency in food and energy. Tinau River management and conservation must aim to have a healthy river that, to the greatest extent possible, is unpolluted, supportive of a wide diversity of life forms, and able to flood in a controlled manner. Maintaining or restoring the watershed forests, wetlands and healthy soils minimizes damaging flash floods and the risk of drought. It also cuts down on soil erosion, increases the ability of the river to break down and filter pollutants, and provides diverse wildlife habitat.

Each type of water/resource use in the basin is managed in a fragmented manner by separate departments or agencies. Problems of uncoordinated and fragmented decision-making abound. For a healthy watershed development, water resources of the river should be managed in a comprehensive manner. Policies, framework, methodology, legislation and institutions are to be developed and established for IWRM of the river. The present sets of laws do have certain provision to check the illegal use or abstraction of the water or other resources of the river, but there is an issue of initiative lacking in our institutions.

Reliable hydrological, meteorological, geological and land use data for the entire watershed have to be regularly collected. Watershed management should be an important consideration for sustainability of future Tinau development. It is not an easy task. It requires simultaneous achievement of many tasks, including afforestation, strict control of land use practices, and more emphasis on small-scale structures such as check dams for better soil and water conservation.

This paper was presented at the Seminar entitled 'Adaptation in Climate Change and River Conservation for better Livelihood and Effective Irrigation System - 
Special Focus on Tinau River, Nepal' jointly organized by Jalsrot Vikas Sanstha (JVS/GWP Nepal), Kathmandu, Nepal Engineers' Association, Lumbini Regional Centre, Butwal, and NATURE, Butwal held on 22-23 July, 2011.

Som Nath Poudel, M.E. Water Resources and M.A. Nepali Lit. is the former Executive Secretary of Water and Energy Commission Secretariat, Government of Nepal (GON). He is the Vice-Chairman of Jalsrot Vikas Sanstha (JVS). He was the Coordinator for Ten Year Hydropower Development Plan Formulation Taskforce, 2065 (2009) and the High Level Committee for Monitoring and Inspection of Infrastructure Projects, 2010, GON.

Corresponding Address: poudelsn@gmail.com

\section{References}

DOI, 1994, Reassessment of the Groundwater Development Strategy for Irrigation in the Terai, GWRDP, Volume 1-4, Kathmandu: Department of Irrigation.

DOI, 1999, Bhairawa-Lumbini Groundwater Irrigation Project, (HMGN), GWRDP, Stage III, Project
Completion Report, Final, Kathmandu: Department of Irrigation.

Dhungel D. N. and S.B. Pun (eds.), 2009, Nepal-India Water Resources Relationship: Challenges, London: Springer.

Dahal K. R., 2009, Ph. D. Proposal, Submitted to Kathmandu University (with Permission of the Author).

Moench M., E. Caspari and A. Dixit, 1999, Rethinking the Mosaic: Investigations into Local Water Management, Kathmandu: Jagadamba Press.

Poudel S. N., 1986, Irrigation Development in Nepal, Manaslu press, Kathmandu.

Poudel S. N., 2002, Nepalma Sinchai (Nepali), Jalsrot Vikash Sanstha, Kathmandu.

Pradhan P. and Gautam U., 2005, Farmer Managed Irrigation Systems and Governance Alternatives, Kathmandu: Farmer Managed Irrigation Systems Promotion Trust (FMIST).

Yoder R., 1994, Organization and Management by Farmers in Chhatis Mauja Irrigation System, Colombo, Sri Lanka: International Irrigation Management Institute (IIMI).

\section{NESS}

\section{Nepal Environmental \& Scientific Services [NESSI Private Limited GPO Box 7301, Thapathali Kathmandu, Nepal \\ Tel: +977 01 4244989, 4241001, Fax: +97701 4226028 \\ Url : http://www.ness.com.np, Email : ness@mos.com.np}

The NESS is well recognized and specialized leading consulting and laboratory firm in the field of

Engineering, Environment, Social Assessment; and Management Studies and Analytical Services. In recognition to the services provided, NESS was honored with "Environment Excellence Award, 2003" by the Ministry of Population and Environment (MOPE) of Government of Nepal.

\section{First accredited Well Equipped Environmental Laboratory in $\mathcal{N e p a l}$ \\ Enlisted in MoEST and MoAC. \\ Laboratory Management System is guided by QCM.}

Successfully completed the Consulting Services for more than 200 Infrastructure Development Projects

\section{Consulting}

- Geological, geo-technical, topographical, meteorological and geophysical survey; biological and ecological surveys;

- IEE and EIA studies (Auditing / Monitoring)

- Preparation of Environmental policies, EMP, resettlement \& rehabilitation plans for infrastructure development projects

- Water/wastewater and industrial pollution management and design of pollution treatment systems;

- Designing Waste Management Plans and Special Waste Management Plans for different Projects;

- Watershed management;

- Consulting on socio-economic and engineering fields; SIA, Design and Implementation of social support programs for large infrastructure development projects;

- Project management, conflict management; public dialogue

\section{Loboratory}

- Accredited analytical services for water \& wastewater, cement, sand \& aggregates, fertilizer, soil, food products, sprit \& alcoholic drinks, air pollutant, pesticides, coal, plant matter, rock \& minerals, brick \& ceramic, molasses.

- Air quality management, monitoring and chemical analysis;

- Monitoring and analysis of noise and vibration;

- Quality control and chemical analysis (inorganic, organic, metals, microbiological and pesticides) of raw materials and industrial products; and

- Research \& development 